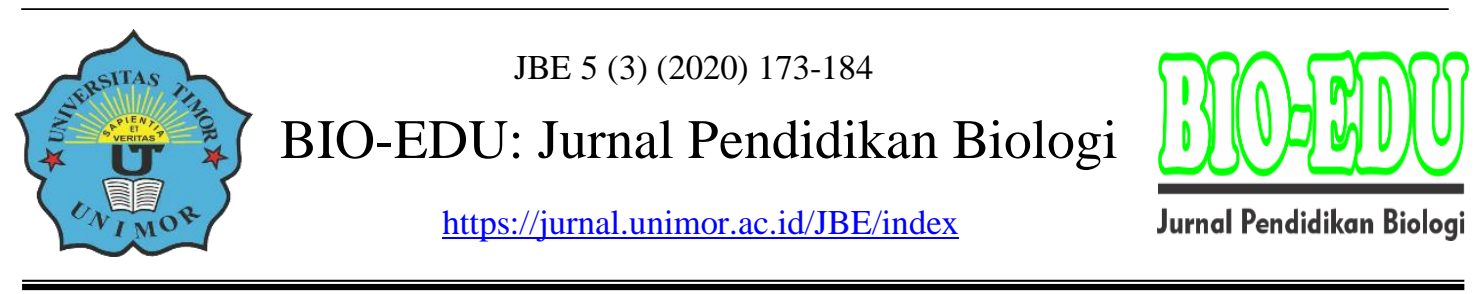

\title{
Diversity of Food Source and Foraging Behavior of Tetragonula laeviceps (Hymenoptera: Meliponini) in South Parigi Sub District
}

\author{
Keanekaragaman Sumber Pakan dan Perilaku Mencari Pakan \\ Lebah Tetragonula laeviceps (Hymenoptera: Meliponini) di \\ Kecamatan Parigi Selatan
}

\author{
Nuraini, Manap Trianto, Sukmawati, Fajri Marisa \\ Departemen Biologi Tropika, Fakultas Biologi, Universitas Gadjah Mada \\ E-mail: manaptrianto@mail.ugm.ac.id
}

DOI: https://DOI 10.32938/jbe.v5i3.735

\begin{abstract}
Abstrak
Tetragonula laeviceps merupakan jenis lebah madu tanpa sengat yang saat ini banyak dibudidayakan oleh masyarakat Indonesia karena mampu menghasilkan produk yang memiliki banyak kegunaan bagi kehidupan manusia. Perilaku mencari pakan merupakan aktivitas utama lebah madu untuk memenuhi kebutuhan hidupnya. Ketersediaan sumber pakan merupakan salah satu faktor penting yang mempengaruhi perilaku mencari pakan lebah Tetragonula laeviceps. Penelitian ini bertujuan untuk mengetahui keanekaragaman sumber pakan dan perilaku mencari pakan lebah Tetragonula laeviceps. Pengamatan kaeanekaragaman sumber pakan melalui identifikasi polen serta pengamatan perilaku lebah dalam mencari pakan. Hasil penelitian menunjukkan bahwa keanekaragaman polen di Kecamatan Parigi Selatan menunjukkan bahwa terdapat 20 famili sumber pakan Tetragonula laeviceps dan famili yang paling sering dikunjungi yaitu Arecaceae. Perilaku mencari pakan Tetragonula laeviceps dimulai saat terbitnya matahari hingga petang. Puncak aktivitas terjadi pada pagi hari sekitar pukul 08.30-08.40 WITA dan sore hari sekitar pukul 15.30-15.40 WITA yang berkaitan dengan ketersediaan sumber pakan. Faktor lingkungan yang meliputi temperatur udara, kelembaban udara, dan intensitas cahaya mempengaruhi perilaku mencari pakan Tetragonula laeviceps.
\end{abstract}

Kata Kunci: Keanekaragaman; Parigi Selatan; perilaku; sumber pakan; Tetragonula laeviceps

\begin{abstract}
Tetragonula laeviceps is a type of stingless bee that is currently widely cultivated in Indonesia due to ability to produce various products that have many uses for human life. Foraging behavior is the main activity of honey bee to fulfill their daily needs. The availability of food source is one of the important factor that influence the foraging behavior of Tetragonula laeviceps. This study aims to determine the diversity of food source and foraging behavior of Tetragonula laeviceps. Observing the diversity of food source through identification of pollen and observing the foraging behavior of the bee. The diversity of pollen found in Parigi Selatan Regency showed that there were 20 families of food sources of Tetragonula laeviceps and the most frequently visited family is Arecaceae. Foraging behavior of Tetragonula laeviceps begins at sunrise until evening. The peak of activity occurs in the morning around 08.30-08.40 WITA and the afternoon around 15.30-15.40 WITA which is related to the availability of food source. Environmental factors (air temperature, humidity, and light intensity) affect the foraging behavior of Tetragonula laeviceps.
\end{abstract}


Keywords: Diversity; South Parigi; foraging behavior; food source; Tetragonula laeviceps

\section{PENDAHULUAN}

Indonesia merupakan negara beriklim tropis yang memiliki keanekaragaman flora dan fauna tinggi sehingga dijuluki sebagai Spot of Megabiodiversity. Salah satu keanekaragaman fauna yang dimiliki adalah lebah madu. Lebah madu banyak dibudidayakan oleh masyarakat Indonesia karena produk yang dihasilkan diketahui memiliki banyak kegunaan bagi kehidupan manusia (Trianto et al., 2020: 199-209). Lebah dikenal memiliki sengat sebagai bentuk pertahanan diri, namun berbeda dengan lebah Trigona yang tergolong ke dalam lebah tak bersengat (stingless bee). Trigona merupakan serangga sosial yang hidup berkoloni dan cocok berada pada daerah beriklim tropis dan dataran rendah. Produk yang dihasilkan lebah Trigona adalah madu, bee bread, bee pollen, propolis, royal jelly, dan lilin lebah (beeswax) (Suranto, 2010: 13-15; Suprianto, 2020: 30-39; Trianto et al., 2020: 154-162). Propolis digunakan lebah untuk menjaga kestabilan suhu di dalam sarang dan melindungi sarangnya dari serangan predator. Jumlah madu yang dihasilkan lebah Trigona lebih sedikit, namun jumlah propolis yang dihasilkan lebih banyak dibandingkan dengan lebah jenis lain. Hal ini dikarenakan propolis merupakan bahan utama yang digunakan sebagai usaha pertahanan diri dari serangan predator (Riendriasari dan Krisnawati, 2017: 71-75; Trianto dan Purwanto, 2020: 2619-2628). Madu yang dihasilkan lebah Trigona memiliki karakteristik yang khas yaitu terasa asam tetapi tahan terhadap fermentasi serta harga madunya lebih mahal bila dibandingkan dengan madu produksi lebah Apis (Suranto, 2010: 14-15; Trianto dan Marisa, 2020: 29-33).

Salah satu faktor penting yang dapat mempengaruhi perilaku lebah Trigona dalam mencari pakan yaitu keberadaan sumber pakan di sekitarnya. Ketersediaan sumber pakan yang melimpah dapat meningkatkan aktivitas lebah pekerja dalam mengambil polen dan nektar pada tanaman. Selain itu, aktivitas harian lebah Trigona dapat terlihat dari aktivitas keluar masuk sarang dalam upaya untuk menjaga sarang dari serangan predator serta membersihkan kotoran yang terdapat di dalam sarang. Tanaman pakan yang sering dikunjungi lebah madu diantaranya adalah Impatiens balsamina, Carica papaya, Ageratum houstonianum, Psidium guajava, Helianthus sp., Acacia sp., Caliandra brevipes, Mimosa pudica, Capsicum sp. dan Cocos nucifera (Ramalho et al., 1990: 469488; Trianto et al., 2020: 154-162). Adapun tanaman jenis lainnya yaitu Leucas aspera, Ocimum sanctum, dan Tridax procumbents (Kumar et al., 2012). Selain itu, beberapa faktor lain yang dapat mempengaruhi aktivitas harian lebah madu di dalam mencari pakan yaitu jarak sumber pakan, temperatur udara, kelembaban udara, dan intensitas cahaya (Shaara, 2014: 1-10; Trianto et al., 2020: 21-29).

Berdasarkan penjelasan diatas, maka dipandang perlu dilakukan penelitian mengenai keanekaragaman sumber pakan serta perilaku mencari pakan Trigona sebagai makan dalam manajemen pemeliharaan Trigona secara tepat serta melakukan upaya untuk mengembangkan perlebahan Trigona, salah satunya yaitu dengan penyediaan sumber pakan di sekitar tempat peletakan koloni lebah Trigona.

\section{METODE}

\section{Waktu dan Tempat Penelitian}

Penelitian ini dilaksanakan pada bulan Februari-Maret 2019 di Kecamatan Parigi Selatan. Jenis penelitian ini adalah penelitian deskriptif eksploratif, dilakukan pada lokasi 
peternak lebah Tetragonula laeviceps.

\section{Alat dan Bahan}

Bahan yang digunakan untuk identifikasi serta pengamatan aktivitas lebah Tetragonula laeviceps yaitu sampel lebah dan alkohol 70\%. Alat yang digunakan yaitu hand counter untuk menghitung lebah yang keluar masuk sarang, botol flakon 10 buah berukuran $10 \mathrm{ml}$ untuk menyimpan sampel lebah, thermohigrometer untuk mengukur temperatur dan kelembaban udara, luxmeter untuk mengukur intensitas cahaya, log book, alat tulis, mikroskop cahaya dan Digital Microscope Supereyes untuk mengamati morfologi lebah, jarum, dan gelas benda.

Bahan yang digunakan untuk identifikasi polen yaitu koloni lebah, air, polen yang diambil dari kantung polen pada sarang lebah, akuades, larutan asam klorida 25\%, kalium hidroksida 25\%, safranin, alkohol absolut, gliserin dan kertas label. Alat yang digunakan yaitu conicle tube sebanyak 4 buah untuk menyimpan polen yang diambil dari sarang lebah Trigona, pipet tetes, pipet ukur, gelas beker, gelas benda, degglass, sentrifuge, waterbath, vortex, batang gelas (kaca pengaduk), mikroskop cahaya dan kamera.

\section{Pelaksanaan Penelitian}

\section{Identifikasi polen pada sarang lebah Tetragonula laeviceps.}

Identifikasi polen dilakukan dengan cara mengamati setiap preparat polen yang diambil dari sarang lebah khusunya yang diambil dari kantung polen (pollen pots). Selain itu, identifikasi juga dilakukan dengan menggunakan situs Australian Pollen and Spore Atlas

(http://apsa.anu.edu.au) dan buku identifikasi serbuk sari Pollen Flora of Taiwan untuk penentuan famili tumbuhan. Identifikasi polen dilakukan dengan pembuatan preparat polen menggunakan metode asetolisis dengan adanya beberapa variasi perubahan (Hesse et al., 2009: 51-52). Cara kerja dari metode ini yaitu pertama-tama dilakukan pengenceran sampel polen dengan cara 5 gr sampel polen yang diambil dari kantung polen (pollen pots) pada sarang lebah dimasukkan ke dalam conicle tube dan ditambah $7 \mathrm{ml}$ akuades kemudian disentifugasi dengan kecepatan $1700 \mathrm{rpm}$ selama 5 menit. Kemudian, supernatan dibuang sehingga pelet hanya terdiri dari polen dan beberapa materi organik. Kemudian, ditambahkan larutan asam klorida $25 \%$ sebanyak $7 \mathrm{ml}$ untuk menghilangkan molekul organik lalu digojog sehingga larutan tercampur merata pada pelet. Setelah itu, dipanaskan selama 30 menit dengan temperatur $100^{\circ} \mathrm{C}$ lalu disentrifugasi dengan kecepatan $1700 \mathrm{rpm}$ selama 5 menit dan supernatan dibuang. Pada tahapan ini dilakukan tiga kali pengulangan.

Selanjutnya, bahan dinetralkan pH-nya dengan penambahan larutan kalium hidroksida $25 \%$ sebanyak $7 \mathrm{ml}$, disentrifugasi dengan kecepatan 1700 rpm selama 5 menit dan supernatan dibuang. Tahapan ini juga dilakukan tiga kali pengulangan. Kemudian, dilakukan pencucian dengan akuades beberapa kali sampai kalium hidroksida dan molekul organik hilang. Pelet ditambahkan tiga tetes pewarna safranin dan disimpan selama 24 jam agar pewarna melekat erat pada dinding serbuk sari. Setelah 24 jam, serbuk sari dicuci dengan akuades dan disentrifugasi sampai sisa pewarna safranin hilang. Selanjutnya, pelet berisi polen diletakkan di atas gelas benda, selanjutnya dianginanginkan sampai air yang ada pada peparat menguap, lalu ditambahkan alkohol absolut sebanyak satu tetes dan ditambahkan setetes gliserin, kemudian gelas benda ditutup dengan gelas penutup. Tahap akhir yaitu dilakukan pengamatan karakter morfologis serbuk sari di bawah mikroskop cahaya dengan perbesaran lensa okuler $10 \times$ dan lensa objektif 100× (Rasyiid, 2017: 31-49).

Pengamatan Perilaku Lebah Tetragonula laeviceps 
Pengamatan aktivitas. keluar masuk sarang dilakukan pada pukul 05.00-18.00 WITA. Pengamatan dilakukan selama tiga hari, berlangsung setiap satu jam sekali selama 10 menit. Pengamatan aktivitas terbang Tetragonula laeviceps dilakukan dengan cara menghitung jumlah lebah pekerja yang keluar dan masuk sarang dengan menggunakan hand counter. Pengamatan kunjungan lebah pada bunga juga dilakukan setiap satu jam sekali selama 10 menit pada pukul 05.00-18.00 WITA.

Pengamatan Parameter Lingkungan

Pengamatan parameter lingkungan berupa temperatur udara, kelembaban udara, dan intensitas cahaya dilakukan bersamaan dengan pengamatan perilaku lebah Tetragonula laeviceps.

\section{Analisis Data}

Morfometri sampel lebah Tetragonula laeviceps dilakukan dengan menghitung nilai rata-rata panjang/lebar/jarak $(\mathrm{mm})$ bagian-bagian tubuh serangga. Selanjutnya, perilaku mencari pakan dapat diketahui dengan menghitung jumlah rata-rata individu Tetragonula laeviceps yang keluar dan masuk sarang serta jumlah rata-rata individu yang mengunjungi bunga. Sedangkan keanekaragaman polen disajikan secara deskriptif.

\section{HASIL DAN PEMBAHASAN}

\section{Keanekaragaman Sumber Pakan Polen Tetragonula laeviceps}

Keanekaragaman sumber pakan polen lebah Tetragonula laeviceps dapat diketahui dengan melakukan identifikasi polen yang diambil dari sarang khususnya yang terdapat di dalam kantung polen (pollen pots). Pengambilan polen dilakukan di dua lokasi peternakan lebah Stingless bees di Kecamatan Parigi Selatan.

\section{Lokasi Peternakan Lebah I}

Keanekaragaman polen di Kecamatan Parigi Selatan pada lokasi pertama yaitu berjumlah 35 famili dan 5 belum teridentifikasi (Gambar 3). Adanya polen yang belum teridentifikasi dikarenakan sulitnya menggolongkan polen ke dalam suatu famili tumbuhan karena tidak ada literatur yang menunjang dan terdapat beberapa famili tumbuhan yang karakter polennya sangat mirip. Dari hasil yang diperoleh, dapat diketahui bahwa Arecaceae merupakan famili yang paling dominan yaitu sebesar 14\% dari jumlah total polen yang ditemukan. Hal ini dapat dikarenakan pada daerah Kecamatan Parigi Selatan banyak ditumbuhi oleh tumbuhan yang berasal dari famili Arecaceae, dan mayoritas lahannya ditanami tanaman salak (Salacca zalacca (Gaertn).Voss) yang merupakan anggota dari famili Arecaceae.

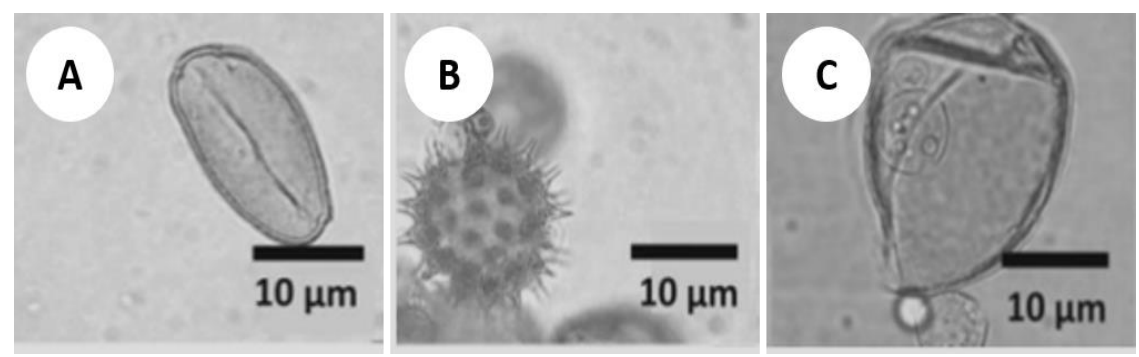

\section{Gambar 1. Preparat polen dari famili Arecaceae (A), Asteraceae (B), dan Cyperaceae (C)}

Arecaceae (Gambar 1) umumnya didominasi oleh tumbuhan menahun (perennial) dan dapat berupa pohon maupun semak. Tumbuhan menahun (perennial) merupakan tumbuhan yang mampu melanjutkan pertumbuhannya hingga kurun waktu lebih dari dua 
tahun. Sedangkan, adapula tumbuhan musiman (annual) yang merupakan tumbuhan yang menyelesaikan siklus hidupnya dalam kurun waktu satu tahun (Simpson, 2011: 402). Batangnya dapat tumbuh secara bergerombol atau soliter, tegak, maupun merambat pada pohon lainnya. Arecaceae tergolong tumbuhan monokotil dengan tinggi batang yang beragam (Baker, 2009: 1-10). Adapun karakter umum yang teramati pada preparat polen Arecaceae yaitu rectangular, monocolpate, psilate dan monad.

Selain itu, polen dari famili Asteraceae dan Cyperaceae (Gambar 1) juga yang paling dominan setelah Arecaceae yaitu masing-masing sebesar 8\% dan $7 \%$. Asteraceae dapat berupa tumbuhan musiman (annual) dan menahun (perennial) serta habitusnya dapat berupa herba, semak, perdu, maupun tanaman memanjat. Sebagian besar dikenal sebagai tanaman liar, tanaman pagar dan tanaman obat-obatan (Hasanudin dan Fitriana, 2014). Karakter umum yang teramati pada preparat polen Asteraceae yaitu circular, lophate atau echinate, tricolporate dan monad.

Cyperaceae dapat berupa tumbuhan musiman (annual) dan tahunan (perennial) serta habitusnya berupa herba. Tumbuhan anggota famili Cyperaceae tergolong tumbuhan monokotil yang terlihat seperti rumput-rumputan (Prata dan Simpson, 2009: 28-40). Karakter umum yang teramati pada preparat polen Cyperaceae yaitu asimetrik, inarpertura, psilate, dan monad.

\section{Lokasi Peternakan Lebah II}

Keanekaragaman polen di Kecamatan Parigi Selatan pada lokasi kedua yaitu berjumlah 16 famili dan 3 belum teridentifikasi. Arecaceae merupakan famili yang paling dominan yaitu sebesar 53\% dari jumlah keseluruhan. Hal ini dapat dikarenakan lokasi tersebut banyak ditumbuhi oleh tumbuhan yang berasal dari famili Arecaceae (Gambar 2) dan terdapat jenis palem yang tumbuh di dekat lokasi penempatan sarang yaitu Hyophorbe lagenicaulis (L.H. Bailey) H.E.Moore (bottle palm) dan Wodyetia bifurcata A.K.Irvine (foxtail palm). Adapun karakter umum yang teramati pada preparat polen Arecaceae yaitu rectangular, monocolpate, psilate dan monad.

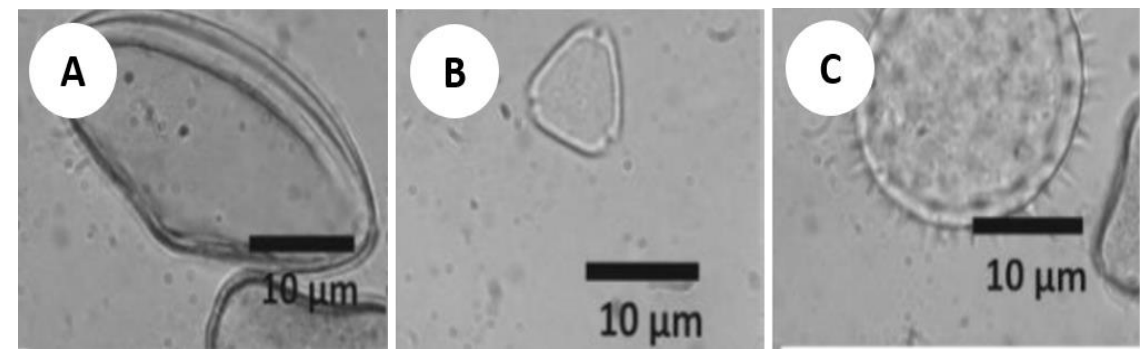

\section{Gambar 2. Preparat polen dari famili Arecaceae (A) Myrtaceae (B) dan Malvaceae (C)}

Selain itu, polen dari famili Myrtaceae dan Malvaceae (Gambar 2) juga yang paling dominan setelah Arecaceae yaitu masing-masing sebesar 6\%. Myrtaceae merupakan tumbuhan menahun (perennial) dan habitusnya dapat berupa pohon maupun semak (Lucas dan Jennings, 2009: 28-34). Pada umumnya, Myrtaceae memiliki karakter bunga yang berukuran kecil dan tergolong bunga majemuk sehingga menjadi daya tarik bagi hewan penyerbuk meliputi serangga, burung maupun kelelawar (Kartikasari et al., 2012: 235). Adapun karakter umum yang teramati pada preparat polen Myrtaceae yaitu triangular, tricholpate, psilate, dan monad. 
Malvaceae dapat berupa tumbuhan musiman (annual) dan tahunan (perennial) serta habitusnya berupa herba, semak maupun pohon. Sebagian besar anggota famili ini memiliki bunga yang sangat mencolok dengan ukuran yang besar dan warna yang bervariasi serta biasanya memiliki benang sari yang jumlahnya banyak (Tambde et al., 2016: 243-353). Adapun karakter umum yang teramati pada preparat polen Malvaceae yaitu circular, pantoporate, echinate, dan monad.

Berdasarkan data dari kedua lokasi tersebut, dapat diketahui bahwa anggota famili Arecaceae merupakan jenis tanaman pakan yang paling dominan di Kecamatan Parigi Selatan. Hal ini dapat dikarenakan bunga Arecaceae memiliki aroma yang harum dan morfologi polen Arecaceae yang memiliki struktur apertura dengan celah yang cukup besar membuatnya mudah terbawa oleh serangga polinator seperti lebah (Asra, 2015: 4043). Kunjungan lebah pada bunga dapat dipengaruhi oleh karakter morfologi bunga yang menjadi attractan atau daya tarik. Daya tarik visual (warna dan pola) atau petunjuk aroma (olfactory cues) penting dalam menarik kunjungan polinator untuk mendapatkan polen dan nektar. Bunga yang penyerbukannya dibantu serangga terutama lebah memiliki waktu anthesis siang hari, warna bunga yang terang dan cerah, beraroma, memiliki nectar guide dan letak nektar yang tersembunyi (Sari dan Putra, 2015: 27-31). Jarak jelajah lebah Trigona spp. mencari pakannya berkisar $\pm 600 \mathrm{~m}$ dari sarang. Namun, ukuran tubuh lebah dapat mempengaruhi jarak jelajah mencari pakan, semakin besar ukuran tubuhnya maka akan semakin jauh pula jarak jelajah dalam mencari pakan (Novita dan Sutriyono 2013: 41-56).

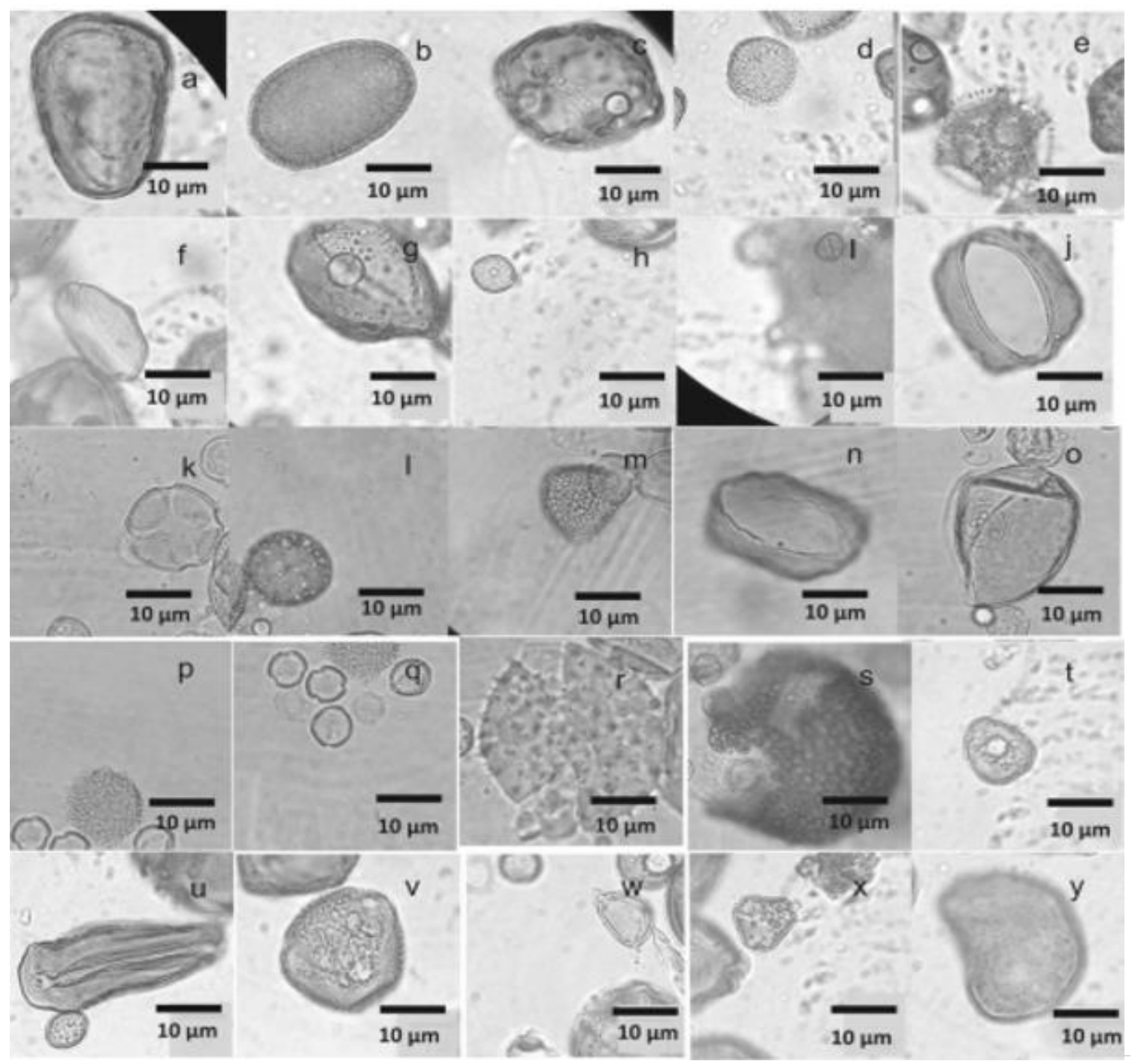

178 I Nuraini et al / JBE 5 (3) ( 2020 ) 173-184 
Gambar 3. Keanekaragaman polen di Kecamatan Parigi Selatan Perilaku Mencari Makan Tetragonula laeviceps

Pola aktivitas mencari makan lebah Tetragonula laeviceps, diketahui dengan melakukan pengamatan dengan menghitung jumlah individu lebah yang terbang keluar dan masuk sarang. Selain itu, dilakukan pengamatan perilaku kunjungan lebah pada bunga Cosmos sulphureus Cav. yang berada di dekat sarang dengan menghitung jumlah individu lebah yang mengunjungi bunga tersebut. Parameter lingkungan yang diukur adalah temperatur udara, kelembaban udara, dan intensitas cahaya (Gambar 5, 6, dan 7). Pengamatan aktivitas lebah keluar dan masuk sarang serta kunjungan pada bunga dilakukan selama tiga hari setiap satu jam sekali dari pukul 05.00 hingga 18.00 WITA, lama pengamatan yaitu \pm 10 menit (Gambar 4 ).

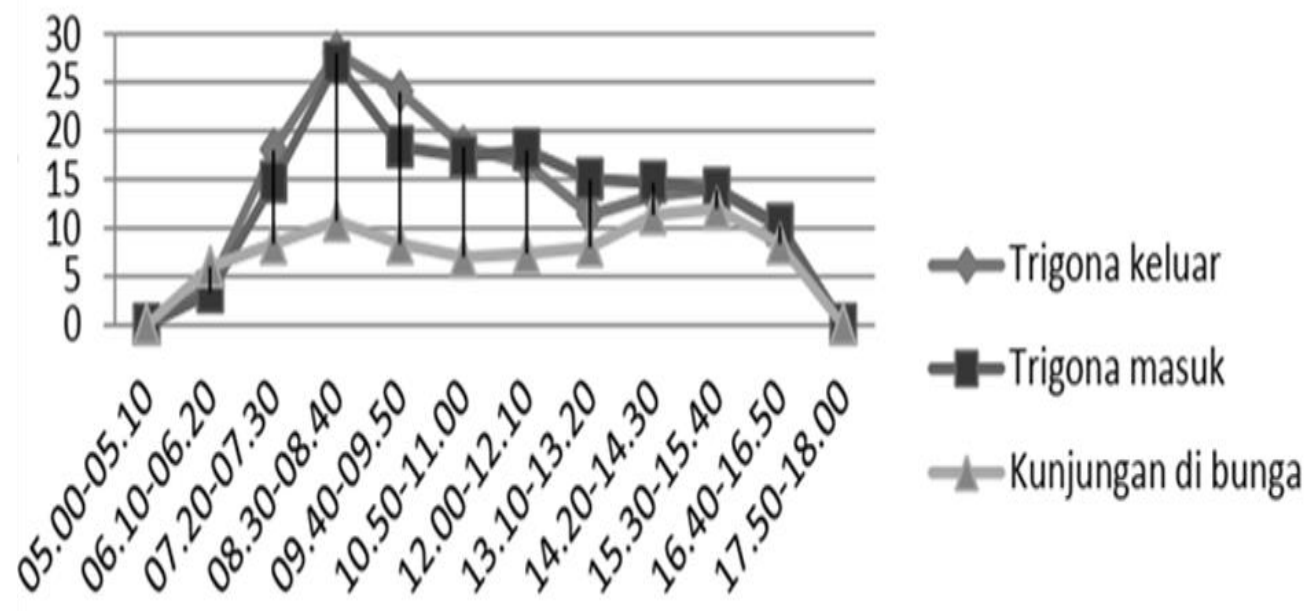

Gambar 4. Aktivitas Tetragonula laeviceps keluar dan masuk sarang serta kunjungan pada bunga Cosmos sulphureus Cav. Vertikal (Jumlah Tetragonula laeviceps), dan Horizontal (Waktu/Jam)

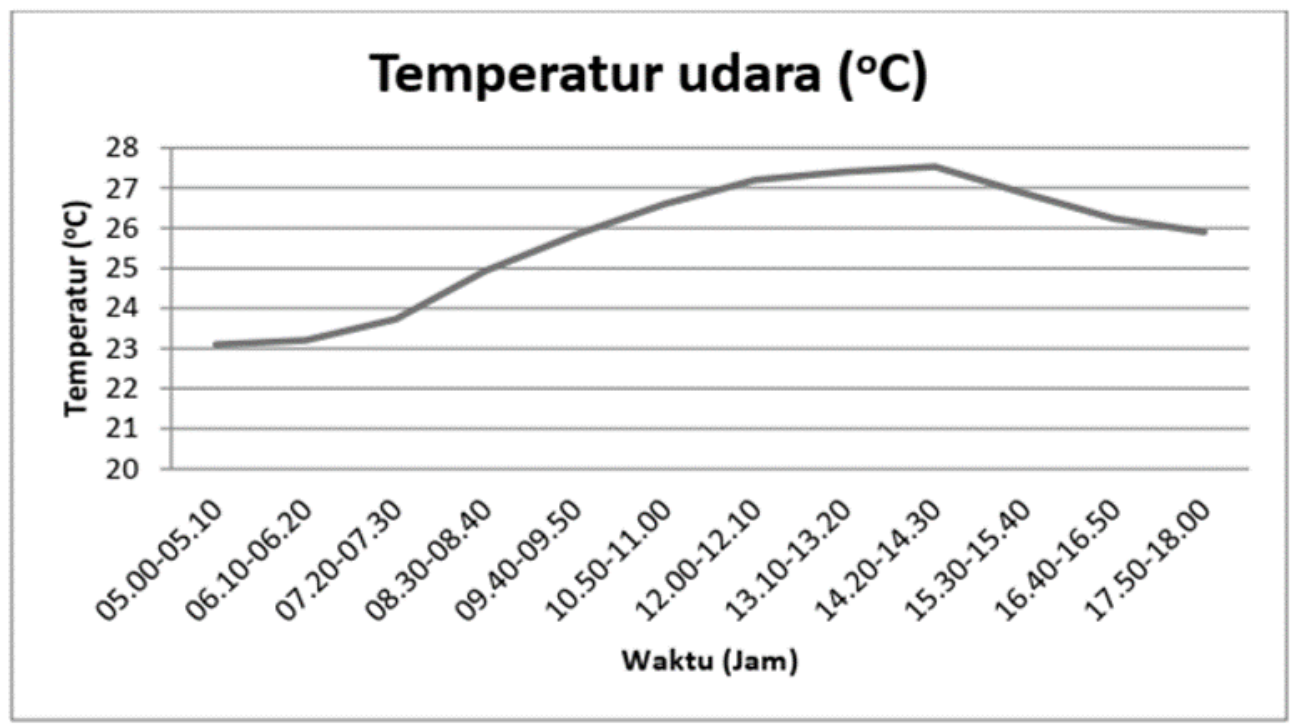




\section{Gambar 5. Hasil pengukuran temperatur udara rata-rata selama tiga hari pengamatan}

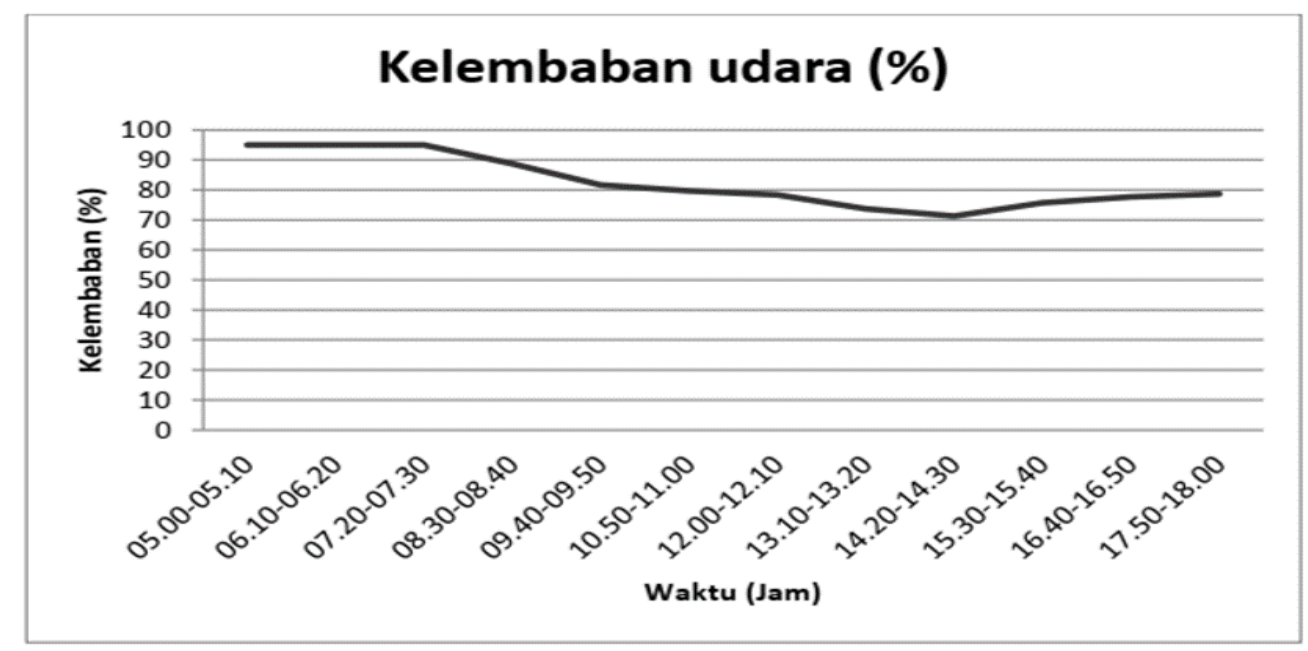

Gambar 6. Hasil pengukuran kelembaban udara rata-rata selama tiga hari pengamatan

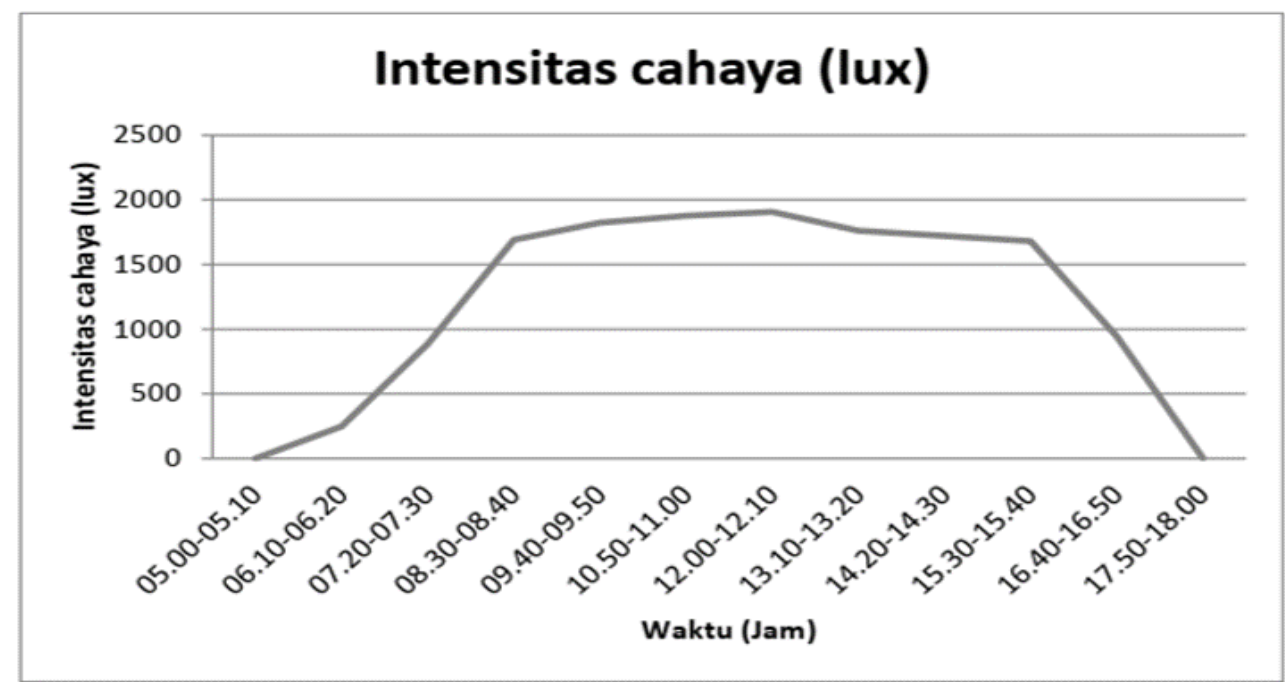

\section{Gambar 7. Hasil pengukuran intensitas cahaya rata-rata selama tiga hari pengamatan}

Berdasarkan grafik di atas, dapat diketahui bahwa aktivitas terbang Tetragonula laeviceps mencari pakan dimulai saat terbitnya matahari hingga petang. Pada pukul 05.00-05.10 tidak terlihat adanya Tetragonula laeviceps yang beraktivitas karena matahari belum terbit sehingga kondisi lingkungan masih gelap, sedangkan pukul 06.1006.20 mulai terlihat adanya Tetragonula laeviceps yang beraktivitas, ditunjukkan dengan adanya individu yang keluar masuk sarang serta individu yang mengunjungi bunga dengan temperatur udara $23,2^{\circ} \mathrm{C}$, kelembaban udara $95 \%$ dan intensitas cahaya sebesar 248 lux (Gambar 5, 6, dan 7). Hal tersebut sesuai dengan pernyataan Gobatto dan Knoll (2013: 367-373) bahwa aktivitas lebah dapat dipengaruhi oleh kondisi lingkungan terutama temperatur udara, kelembaban udara, intensitas cahaya, kondisi internal sarang dan ketersediaan pakan. Selain itu, Contrera et al. (2004: 35-43) juga menyatakan bahwa 
indikator adanya aktivitas lebah dapat dilihat dari jumlah lebah yang keluar dari sarang.

Puncak aktivitas keluar masuk sarang Tetragonula laeviceps terjadi di pagi hari pada pukul $08.30-08.40$ dengan temperatur udara $24,93^{\circ} \mathrm{C}$, kelembaban udara $88,67 \%$, dan intensitas cahaya 1.690,67 lux. Hal ini dikarenakan ketersediaan pakan lebah jumlahnya melimpah di pagi hari (Macias et al., 2017: 383-387). Menurut Simioni et al. (2015: 137-145), lebah akan sering beraktivitas mengoleksi polen di pagi hari sekitar pukul 08.00-10.00 karena temperatur dan kelembaban udaranya sangat mendukung.

Kemudian, aktivitas Tetragonula laeviceps keluar sarang meningkat kembali pada pukul $15.30-15.40$ dengan temperatur udara $26,77^{\circ} \mathrm{C}$, kelembaban udara $75,67 \%$ dan intensitas cahaya 1.680,67 lux. Sedangkan, aktivitas masuk sarang meningkat kembali pada pukul 12.00-12.10 dengan temperatur udara $27,2^{\circ} \mathrm{C}$, kelembaban udara $78,3 \%$, dan intensitas cahaya 1.906 lux. Puncak aktivitas tertinggi Tetragonula laeviceps yang terjadi di pagi dan sore hari tersebut memiliki kesamaan dengan hasil penelitian Contrera et al. (2004: 35-43) terhadap aktivitas terbang Trigona yang memiliki puncak aktivitas tertinggi pada pukul 10.00-14.00 dan meningkat kembali setelah pukul 14.00, dengan suhu berkisar $22-26^{\circ} \mathrm{C}$.

Berdasarkan pengamatan terhadap bunga Cosmos sulphureus Cav. yang diletakkan di dekat sarang, ditemukan individu Tetragonula laeviceps yang mengunjungi bunga tersebut. Puncak kunjungan lebah terjadi pada pagi hari pukul 08.30-08.40 yaitu sebanyak 10 individu dan kunjungan meningkat kembali pada sore hari pukul 15.3015.40 yaitu sebanyak 12 individu. Dari hasil identifikasi polen yang diambil dari sarang, tidak ditemukan polen dari bunga Cosmos sulphureus Cav. yang merupakan anggota famili Asteraceae. Hal ini dapat dikarenakan Tetragonula laeviceps hanya mengambil nektarnya saja dan tidak mengoleksi polen dari bunga tersebut. Pada kisaran pukul 11.0012.00, kunjungan lebah pada bunga mengalami penurunan jumlah individu dan lebah yang masuk sarang jumlahnya meningkat. Hal ini dikarenakan ketersediaan pakan di sekitarnya mulai berkurang, menjelang siang hari nektar akan mengalami penguapan sehinggga volumenya berkurang (Putra et al., 2017). Ketersediaan nektar pada tanaman melimpah pada pertengahan pagi dan pertengahan sore hari sehingga lebah akan lebih sering berkunjung pada kisaran waktu tersebut (Caron dan Connor, 2013: 139).

Temperatur udara dapat mempengaruhi aktivitas keluar masuknya Tetragonula laeviceps dari sarang, sesuai dengan peryataan Simioni et al. (2015: 137-145) bahwa temperatur udara merupakan faktor yang sangat berpengaruh terhadap aktivitas eksternal lebah. Faktor lainnya yang mempengaruhi aktivitas Tetragonula laeviceps adalah kelembaban udara. Aktivitas terbang lebah menjadi lebih sulit dan menurun bila kelembaban udara meningkat (Alves et al., 2015: 405-409). Cahaya matahari juga faktor penting yang mempengaruhi aktivitas lebah dalam mencari pakan sesuai dengan pernyataan Butler and Finney (1947: 206-212) bahwa cahaya matahari merupakan faktor penting yang mempengaruhi aktivitas lebah karena lebah tidak akan beraktivitas di luar sarang bila temperatur udara terlalu rendah. Aktivitas keluar masuk sarang dan kunjungan pada bunga merupakan kecenderungan gambaran aktivitas yang berkorelasi dengan perilaku mencari pakan Tetragonula laeviceps.

\section{KESIMPULAN DAN SARAN Kesimpulan}

Berdasarkan hasil penelitian yang dilakukan, maka dapat disimpulkan bahwa keanekaragaman pakan polen lebah Tetragonula laeviceps di Kecamatan Parigi Selatan sebanyak 40 famili dan jenis tanaman pakan yang paling dominan adalah anggota famili 
Arecaceae. Selanjutnya, perilaku mencari pakan Tetragonula laeviceps dimulai saat terbitnya matahari hingga petang. Puncak aktivitas terjadi pada pagi hari sekitar pukul 08.30-08.40 dan sore hari sekitar pukul 15.30-15.40 yang berkaitan dengan ketersediaan sumber pakan. Faktor lingkungan yang meliputi temperatur udara, kelembaban udara, dan intensitas cahaya mempengaruhi perilaku mencari pakan Tetragonula laeviceps.

Saran

Perlu adanya penelitian lebih lanjut mengenai perilaku mencari pakan Tetragonula laeviceps pada musim penghujan agar diperoleh data yang lebih lengkap dan dapat diamati perbedaan pola aktivitas yang terjadi pada musim kemarau dan musim penghujan. Selain itu, perlu dilakukan juga pembuatan preparat polen yang diambil langsung dari tanaman pakan untuk dijadikan sebagai preparat pembanding dan memperbanyak sediaan preparat polen agar preparat polen yang dihasilkan dapat terlihat jelas morfologinya dan dapat dapat diidentifikasi dengan baik.

\section{DAFTAR RUJUKAN}

Alves, L.H.S., Cassino, P.C.R., \& Prezoto, F. (2015). Effects of abiotic factors on the foraging activity of Apis Mellifera Linnaeus, 1758 in inflorescences of Vernonia polyanthus Less.

Acta Scientianum Animal Sciences, 37(4), 405-409.

Asra, R. (2015). Serangga pengunjung pada perbungaan jernang rambai (Daemonorops draco (Willd.) Blume). Jurnal Penelitian Universitas Jambi Seri Sains, 17(2), 4043.

Baker, W.J. (2009). Neotropical Arecaceae. http://www.kew.org/science/tropamerica/ neotropikey/ familia/Arecaceae. Diakses pada 28 Juni 2020 pada pukul 19.00.

Butler, C.G., \& Finney, D.J. (1941). The Influence of Variance Physical and Biological Factor of The Enviromental on Honeybee Activity. An Examination of The Relationship Between Activity and Solar Radiation.

Caron, D.M. \& Connor, L.J. (2013). Honey Bee Biology and Beekeping. London: Wicas Press.

Contrera, F.A.L., Fonseca, V.L.I., \& Nieh, J.C. (2004). Temporal and climatological influences on flight activity in the Stingless Bee Trigona hyalinata (Apidae: Meliponini). Tecnologia Ambiente, Criciuma, 10(2), 35-43.

Gobatto, A.L., \& Knoll, F.R.M. (2013). Influence of seasonal changes in daily activity and annual life cycle of Geotrigona mombuca (Hymenoptera: Apidae) in a Cerrado Habitat, Sao Paulo, Brazil. Iheringia, Serie Zoologia, Porto Alegre, 103(4), 367-373.

Hasanudin and Fitriana. 2014. Hubungan Kekerabatan Fenetik 12 Spesies Anggota Familia Asteraceae. Jurnal Edu Bio Tropika, 2(2), 187-250.

Hesse, M., Halbritter, H., Weber, M., Buchner, R., Radivo, A.F Ulrich, S., \& Zetter, R. (2009). Pollen Terminology An Illustrated Handbook. New York: Springer Wien.

Kartikasari, S.N., Marshall, A.J., \& Beehler, B.M. (2007). Ekologi Papua. Yayasan Pustaka Obor Indonesia dan Conservation International.

Kumar, M.S., A.J.A.R. Singh, and G. Alagumuthu. 2012. Traditional Beekeeping of Stingless Bee (Trigona sp.) by Kani Tribes of Western Ghats, Tamil Nadu, India. Indian Journal of Traditional Knowledge, 11(2), 342-345.

Lucas, E., \& Jennings, L. (2009). Neotropical Myrtaceae. http://www.kew.org /science/tropamerica/neotropikey/familia/Myrtaceae. Diakses pada 28 Agustus 2018 pada pukul 19.30 . 
Macias, M.J.O., Gonzalez, J.M.T., and Escareno, F.C. (2017). Foraging behavior, enviromental parameters and nests development of Melipona colimana (Hymenoptera: Meliponini) in temperate climate of Jalisco, Mexico. Brazilian Journal of Biology, 77(2), 383-387.

Novita, R.S., \& Sutriyono. (2013). Analisis morfometrik lebah madu pekerja Apis cerana budidaya pada dua ketinggian tempat yang berbeda. Jurnal Sains Peternakan Indonesia, 8(1), 41-56.

Prata, A.P.N., \& Simpson, D.A. (2009). Neotropical Cyperaceae. http://www.kew.org/science/ tropamerica/neotropikey/familia/Cyperaceae. Diakses pada 29 Juni 2020 pada pukul 18.30.

Putra, D.P., Dahelmi, S., Salmah, \& Swasti, E. (2017). Daily Flight Activity of Trigona laeviceps and T. minangkabau in Red Pepper (Capsicum annuum L.) Plantations in Low and High Lands of West Sumatra. International Journal if Applied Enviromental Sciences, 12(8), 1497-1507.

Ramalho, M., Giovannini, A.K., \& Fonseca, V.LI. (1990). Important bee plants for Stingless Bees (Melipona and Trigonini) and Africanized Honeybees (Apis mellifera) in Neotropical Habitats. Apidologie, 21, 469-488.

Rasyiid, M. (2017). Keragaman Serbuk Sari dan Metabolit Sekunder Pada Madu Hutan Sulawesi Tengah. [Skripsi]. Yogyakarta: Universitas Gadjah Mada.

Riendriasari, S.D., \& Krisnawati. (2017). Produksi propolis mentah lebah madu Trigona spp. di Pulau Lombok. J Hut Trop, 1(1), 71-75.

Sari, D.A., \& Putra, R.E. (2015). Kajian karakter bunga coffea arabica 1. terkait dengan kemungkinan aplikasi lebah madu lokal sebagai agen penyerbuk. Jurnal Matematika \& Sains, 20(1), 27-31.

Shaara, H.F.A. (2014). The foraging behavior of Honey Bees, Apis mellifera: A Review. Veterinarni Medicina. Faculty of Agriculture Damanhour University. Egypt, 59(1), $1-10$.

Simioni, L.C., Mussury, R.M., Mauad, M., Dresh, D.M., Pereira, F., \& Scalon, S.P.Q. (2015). Plant pollinator interactions in crambe abyssinica hochst. (brassicaceae) associated with enviromental variables. Annals of the Brazilian Academy of Sciences, 87(1), 137-145.

Simpson, M.G. (2011). Plant Systematics. Elsevier. Canada: Academic Press.

Suprianto, Trianto, M., Alam, N., \& Kirana, N.G.A.G.C. (2020). Karakter morfologi dan analisis daerah conserved gen elongation factor 1a (EF1a) pada Lepidotrigona terminata. Jurnal Metamorfosa, 7(2), 30-39.

Suranto, A. (2010). Dahsyatnya Propolis untuk Menggempur Penyakit. Jakarta: PT. Agro Media Pustaka.

Tambde, G.M., Gore, R.D., \& Sardesai, M.M. (2016). A synopsis of the Genus Sida L. (Malvaceae) from Maharastra, India. Taiwania, 61(3), 243-252.

Trianto, M., \& Marisa, F. (2020). Diversity of bees and wasp (Hymenoptera) in cowpea (Vigna sinensis L.) in agricultural area at Martapura District, Banjar Regency, South Kalimantan. Journal of Science and Technology, 9(2), 29-33.

Trianto, M., \& Purwanto, H. (2020). Molecular phylogeny of stingless bees in the Special Region of Yogyakarta revealed using partial 16S rRNA mitochondrial gene. Buletin Peternakan, 44(4), 186-193.

Trianto, M., \& Purwanto, H. (2020). Morphological characteristics and morphometrics of Stingless Bees (Hymenoptera: Meliponini) in Yogyakarta, Indonesia. Biodiversitas, 21(6), 2619-2628. 
Trianto, M., Kaini, Saliyem, Warsih, E., \& Winarsih. (2020). Keanekaragaman serangga polinator pada tanaman nanas (Ananas comosus (L.) Merr.) di Desa Bincau. Jurnal Penelitian Science dan Pendidikan, 9(2), 154-162.

Trianto, M., Marisa, F., \& Siswandari, N.P. (2020). Kelimpahan nisbi, frekuensi, dan dominansi jenis lalat di beberapa Pasar Tradisional di Kecamatan Martapura. Jurnal Metamorfosa, 7(2), 21-29.

Trianto, M., Marisa, F., \& Sukmawati. (2020). Keanekaragaman jenis rayap pada perkebunan kelapa sawit dan perkebunan karet di Kabupaten Banjar, Kalimantan Selatan. Jurnal Biologi Makassar, 5(2), 199-209. 